\title{
DETERMINATION OF CHLORIDE ION DIFFUSION COEFFICIENTS FOR ZINC DISSOLUTION IN A LOW TEMPERATURE MOLTEN SALT
}

\author{
Leif R Simonsen and Francis M Donahue
}

Chemical Engineerıng Department, The University of Michigan, Ann Arbor MI 48109-2136, U S A

(Recened 15 December 1988, in revised form 3 April 1989)

\begin{abstract}
The transport properties and stoichiometry of the zanc dissolution process in mixtures of aluminum chloride and 1-methyl-3-ethylimidazolium chloride were studied A new mass transfer correlation for rotating cylinder electrodes was found for these high Schmidt number electrolytes Two limiting current regions were observed durıng the dissolution process which corresponded to a coordination number of four at low overpotentials and a coordination number of three at high overpotentıals The quantity $D \mu / T$ was calculated to be $35 \times 10^{-10}$, which corresponds to a chloride ion radius of $21 \times 10^{-8} \mathrm{~cm}$
\end{abstract}

\section{NOMENCLATURE}

$C_{b} \quad$ bulk concentration, $\mathrm{mol} / \mathrm{cm}^{3}$

$D$ diffusion coefficient or diffusivity, $\mathrm{cm}^{2} / \mathrm{s}$

F Faraday's constant, coulombs/g-equivalent

$l_{d} \quad$ limiting current density, $\mathrm{A} / \mathrm{cm}^{2}$

$k \quad$ Boltzman's constant, erg/molecule $\mathrm{K}$

$k_{c} \quad$ Mass transfer coefficient, $\mathrm{cm} / \mathrm{s}$

$l \quad$ characteristic length (diameter), $\mathrm{cm}$

$\mathrm{N}_{\mathrm{Cl} \text { - }}$ flux of chloride ions, $\mathrm{mole} / \mathrm{cm}^{2} \mathrm{~s}$

$n$ number of electrons transferred

$r \quad$ Ionic radius, $\mathrm{cm}$

$r_{\mathrm{Zn}} \quad$ dissolution rate of zinc, mole $/ \mathrm{cm}^{2} \mathrm{~s}$

$\operatorname{Re}$ Reynolds number, $\left(=U_{m} l / v=\omega l^{2} / 2 v\right)$, dimensionless

$s \quad$ stoichiometric coefficient of the transporting species

Sc Schmidt number, $(=v / D)$, dimensionless

Sh Sherwood number, $\left(=k_{d} l / D=l_{d} / n F D C_{6}\right)$, dimensionless

$T$ temperature, $\mathrm{K}$

$U_{m} \quad$ mean tangential cylinder velocity, $\mathrm{cm} / \mathrm{s}$

$\mu \quad$ viscosity, $\mathrm{cP}$

$v \quad$ kinematic viscosity, $\mathrm{cm}^{2} / \mathrm{s}$

$\omega \quad$ rotation rate, radians/s

Zinc metal has been identified as a possible negative electrode for energy conversion devices utilizing a low temperature molten salt electrolyte based on mixtures of aluminum chloride and 1-methyl-3-ethylImidazolium chloride (MEIC)[1-3] The 1-methyl-3ethylimidazolium ion is the only cationic species present in binary mixtures of these two salts, while the anionic species are dependent on the melt composttion In the basic melt compositions (te mole fraction $\mathrm{AlCl}_{3}<05$ ) the aniontc species present are $\mathrm{Cl}^{-}$and $\mathrm{AlCl}_{4}^{-}$, and in the acidic region (mole fraction $\mathrm{AlCl}_{3}>05$ ) the anionic species are $\mathrm{AlCl}_{4}^{-}$and $\mathrm{Al}_{2} \mathrm{Cl}_{7}^{-}$ "Neutral" melts are defined as those where $\mathrm{AlCl}_{3}$ and MEIC are equimolar, te where $\mathrm{AlCl}_{4}^{-}$is the only anionic species The addition of non-reactive solvents to these melts ( $i e$ benzene or acetonitrile in basic melts) have been shown to improve some transport characteristics, in particular, decreasing viscosity $[4,5]$

The coordination chemistry of zinc with chloride ions in these molten salts has been studied indirectly using proton NMR spectroscopy of the organıc cation[6] It was proposed that at high chloride concentrations the coordination number of zinc is four, while at very low chloride concentration the coordination number is three

Rotatıng cylınder electrodes were selected for use in the major part of this study due to the relative insensitivity of the mean mass transfer coefficient to changes in the electrode surface morphology when operated in a turbulent flow regime Several mass transport correlations exist for rotatıng cylinder electrodes under turbulent flow conditions[7-10], each with the following general dimensionless form

$$
S h=\text { const } \boldsymbol{R e}^{b} S c^{c}
$$

where the $S h$ is the Sherwood number, $R e$ is the Reynolds number, and $S c$ stands for the Schmidt number, while $b$ and $c$ are experımentally determıned constants These correlations indicate that $071>b>060$, while $040>c>033$

This paper focuses on the electrodissolution of zinc and transport properties of the melt-specifically the chloride ion diffusivity-at rotating cylinder and rotatıng disk electrodes in basic compositions of this low temperature molten salt system Experıments were conducted in both binary melts and ternary solutions containıng acetonitrile as a cosolvent

\section{EXPERIMENTAL}

The synthesis and purification of the MEIC was conducted in a manner similar to that of Wilkes and coworkers[11] Alumınum chlonde was purified by vacuum sublimation at $170^{\circ} \mathrm{C}$ from a mixture of commercially avaılable alummum chloride (Fluka puriss), sodium chloride and aluminum wire Acetonitrile was distilled over $\mathrm{P}_{2} \mathrm{O}_{5}$ All reagents were stored under a nitrogen and helium atmosphere in a Vacuum Atmospheres Co glove box All experiments were conducted in the same environment The moisture level was maintained below $1 \mathrm{ppm}$, whle the oxygen level was maintained below $10 \mathrm{ppm}$ 
The proton NMR data of the number 2 carbon of the organic cation, used for determination of the zinc-chloride ion coordination numbers, were initially made on a JEOL $90 \mathrm{MHz}$ spectrometer at F J Seller Research Laboratory[6] Similar experiments were conducted in this study on a Bruker FT/NMR $200 \mathrm{MHz}$ spectrometer NMR spectra used for melt composition determination were run on the Bruker instrument and analyzed by a method reported by Wilkes and coworkers[12]

Proton NMR spectra were taken of each of the binary solutions before and after mass transport experiments to insure that the change in the electrolyte composition (le chloride ion concentration) had been minimized In all cases no observable differences were noted in the NMR spectra

Electrolyte compositions selected for this study were limited to basic melts where the anionic species present are $\mathrm{Cl}$ and $\mathrm{AlCl}_{4}$ Electrolytes chosen for analysis consisted of melts with binary mole fraction of aluminum chloride of 0495,0490 and 0485 Experiments conducted with the cosolvent were carned out at both 5 and $13 \mathrm{wt} \%$ acetonitrile in each of the above compositions The chloride ion concentrations studied were between 74 and $276 \mathrm{mM}$

Densitics and viscositics of the binary solutions were computed from previously determined correlations [5] The use of acetonitrile in some experiments necessitated the measurement of these properties for those solutions Density measurements were made using a Mettler/Paar Model DMA 40 digital density meter, while viscosity measurements were made using a Brookfield Model LVTD plate and cone viscometer All electrochemical and physical property measurements were made at $25^{\circ} \mathrm{C}$

Due to changes in the electrode surface ( $e g$ roughening) during the metal dissolution process, the working electrodes chosen for this study were rotating cylinder electrodes operated at rotation rates sufficiently high to insure fully developed turbulent flow All experiments were conducted using a three electrode arra-

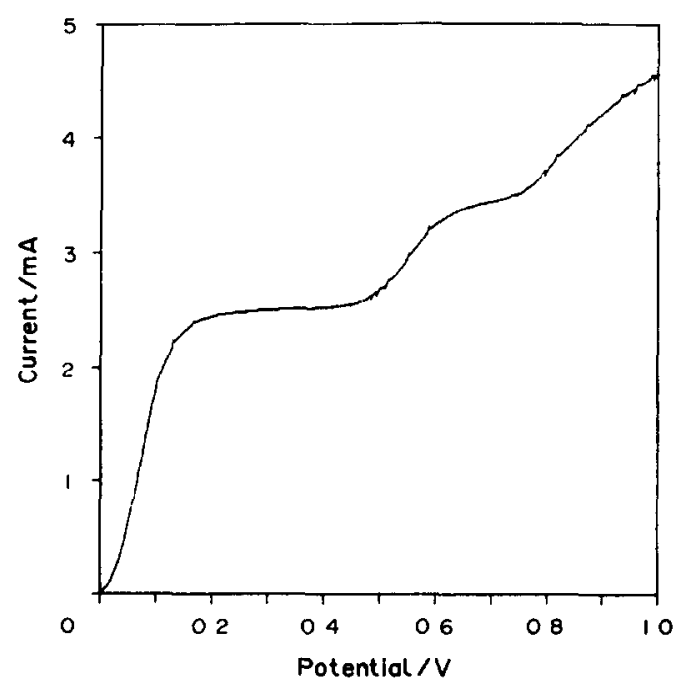

Fig 1 Linear sweep voltammogram of a zınc rotatıng cylınder electrode in an $X=0490$ binary electrolyte (Rotation rate $=1000 \mathrm{rpm}$, scan rate $=1 \mathrm{mV} \mathrm{s}^{-1}$ ) ngement The zinc rotating cylinder clectrodes were fabricated in-house with Johnson Matthey (m5N) zinc, and measured $5 \mathrm{~mm}$ high and $625 \mathrm{~mm}$ in diameter Rotation of the electrode was provided by a Pine Rotator (Model MSR) The cells in which experiments were conducted consisted of a $25 \mathrm{~mm}$ glass cylinder with side ports for the introduction of the counter and reference electrodes The counter electrode was a zinc cylinder (m5N), which was separated from the working electrode compartment with a fine porosity glass frit (Witeg Scientific, Anaheim, CA, Catalog \#2 350 P4) Separation of the electrolyte in these experiments was necessary to prevent intrusion of the reduction product (apparently from the organic cation) into the test electrolyte

The reference electrode was constructed in-house with an aluminum-plated platınum wire immersed in a binary electrolyte which had an $\mathrm{AlCl}_{3}$ mole fraction of 0505 , which was separated from the bulk electrolyte with an ultra-fine porosity glass frit (Witeg Scientific, Anaherm, CA, Catalog \#2 350 P5)

Rotatıng disk electrodes consisted of a $625 \mathrm{~mm}$ zinc rod which was insulated on the sides by a PTFE sleeve $325 \mathrm{~mm}$ thick Rotating disk expenments were conducted in the above cells with the same counter and reference electrodes

Electrochemical measurements were made using a PARC Model 273 Potentıostat-Galyanostat equipped with a current interrupt $I R$ compensation device The PARC Headstart software was used in conjunction with an IBM PC/XT to collect and store the data on 'floppy' disks When noise was encountered in the measurements ( $e g$ at high rotation rates at the RCE), the current data were 'tıme-averaged' using 100 data point sets

\section{RESULTS}

Figure 1 is a linear sweep voltammogram (scan rate $=1 \mathrm{mV} \mathrm{s}^{-1}$ ) for electrodissolution of a zinc rotating cylinder electrode (rotation rate $1000 \mathrm{rpm}$ ) in an $X=0490$ binary electrolyte Two limiting current regions were found This behavior was present in both the $X=0495$ and 0490 binary melts The solutions containing acetonitrile and the higher $\mathrm{Cl}^{-}$concentration binary exhıbited only one distınct limitıng current region around $350 \mathrm{mV}$

Figure 2 is representative of the zinc dissolution reaction at different rotation rates for the first limiting current region in these electrolytes The data presented are for an $X=0495$ melt The "noise" evident in each of the scans is a consequence of the turbulent flow of the system Diffusion coefficients were calculated from limiting current measurements made by fixing the electrode potential and changing the rotation rate of the electrode while monitoring the current flowing in the cell

\section{DISCUSSION}

A detalled analysis of the data, based on logarithmic plots of Sherwood, Reynolds, and Schmidt numbers, revealed that the Reynolds number exponent was $050 \pm 002$ while that for the Schmidt number was 


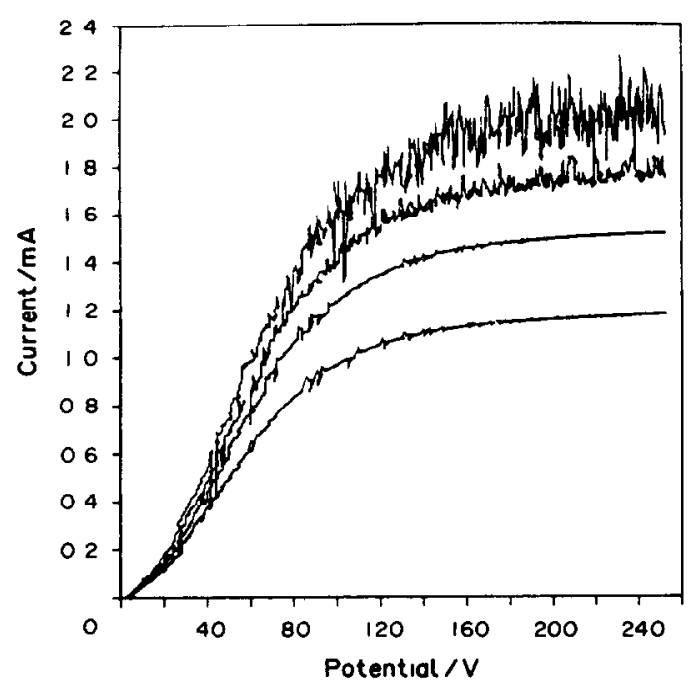

Fig 2 Linear sweep voltammograms of a zinc rotatıng cylinder electrode in an $X=0495$ binary electrolyte (Rotation rates in order of increasing current are 1000, 2000,3000 and $4000 \mathrm{rpm}$, scan rate $=1 \mathrm{mV} \mathrm{s}^{-1}$ )

$033 \pm 002$ The mass transport correlation determined in this study was

$$
S h=039 R e^{1 / 2} S c^{1 / 3}
$$

The Schmidt number dependence is in good agreement with values reported in previous studies $[7,8,10]$, however the Reynolds number dependence was smaller than values reported by others Previous work involved aqueous systems with Schmidt numbers in the range 1900 to 50,000 , while this study covered a greater range of high Schmidt numbers, from 14,000 to 360,000 A similar trend towards a smaller Reynolds number dependence can be noted in data by Eisenberg et al [13] Deviations from their reported 07 power dependence are evident at lower Reynolds numbers $(1000-4000)$ for a system with a relatively high Schmidt number $(10,910)$

The existence of two mass transfer limited dissolution regimes at a constant chloride ion flux is shown in Fig 1 In the experiments reported here the rotation rate of the cylinders and disks were fixed as well as the concentration of the transporting species $\left(\mathrm{Cl}^{-}\right)$ Therefore, the maxımum rate of mass transport (ie maxımum flux), $\mathrm{N}_{\mathrm{Cl}}$, of the chloride ion was also fixed The observed increase of current density at the higher overpotentials cannot be due to increases in the flux of the chloride ions The dissolution rate of zinc, $r_{\mathrm{Zn}}$ is related to the current density, $l$, at the test electrode by

$$
r_{\mathrm{Zn}}=l / 2 F
$$

The chemical reaction responsible for the dissolution process can be written in the form

$$
\mathrm{Zn}+s \mathrm{Cl}^{-} \rightarrow \mathrm{ZnCl}_{s}^{(S-2)-}+2 e^{-}
$$

At the steady-state at large overpoentials (when the process is expected to be controlled by the flux of chloride ions), the relationship between the dissolution rate for zinc metal and the mass transport rate for chloride ion is

$$
r_{\mathrm{Zn}}=l_{\mathrm{d}} / 2 F=N_{\mathrm{Cl}^{-}} / s
$$

or

$$
s l_{d}=\text { constant }
$$

The larger limiting current densities, therefore, are associated with a smaller stoıchıometric coefficient for the chloride ion in the dissolution equation The ratio of the limiting current densities was 133

The equation used for the calculation of diffusion coefficients at rotating cylinder electrodes is

$$
D=l_{d} l s / K n F C_{b} R e^{1 / 2} S c^{1 / 3}
$$

where $K$ is a constant, $n$ is the number of electrons transferred, $F$ is Faraday's constant, $C_{b}$ is the bulk concentration of the transporting species, and $s$ is the absolute value of the storchiometric coefficient of the transporting species Diffusivities were computed from the data at the lower overpotentials in the $X=0495$ and 0490 binary melts and the other solutions on the basis of $s=4$ At higher overpotentials in the $X=0495$ and 0490 , the computations were performed on the basis of $s=3$ (consistent with the comments above) Calculated values of diffusion coefficients for the chloride ion in the various solutions tested are presented in Table 1 The potential values reported for the $X=0490$ and 0495 binary systems refer to the two regions where limiting currents were observed during the zinc dissolution process Included also are the relevant physical properties of the individual solutions used in the determination of the diffusion coefficients The $D \mu / T$ group permits direct comparison of diffusivity values among solutions of varying viscosity

On the basis of these computations from limiting current density measurements, the stoichiometry of the zinc dissolution process at moderate dissolution rates is proposed to be

$$
\mathrm{Zn}+4 \mathrm{Cl}^{-} \rightarrow \mathrm{ZnCl}_{4}^{2-}+2 e^{--}
$$

and, at high zinc dissolution rates, it is proposed to be

$$
\mathrm{Zn}+3 \mathrm{Cl}^{-} \rightarrow \mathrm{ZnCl}_{3}^{-}+2 e^{-}
$$

It is proposed that at the high values of overpotentıal, the reaction rate is sufficiently great that the zinc dissolution process is occurring with the formation of the $\mathrm{ZnCl}_{3}^{-}$species which is transported into the bulk electrolyte before reacting with an additional chloride ion to form the stable $\mathrm{ZnCl}_{4}^{2-}$ anion

In order to assess the validity of this new correlation, diffusivity measurements were performed with an $X=0490$ melt using a rotating disk electrode Chloride ion diffusivity values were then calculated using the Levich equation[14],

$$
l_{d}=062 n F / D^{2 / 3} v^{-1 / 6} C_{b} \omega^{1 / 2}
$$

and are included in Table 1 for comparison It was found that the average diffusivity values for the chloride ion determined by the two electrode systems were in excellent agreement with each other-substantiatıng the new mass transport correlation

The quantity, $D \mu / T$, can also be used to estımate the radius of the transporting species The Stokes-Einstein equation for a spherical particle diffusing in a solution with no slip at the particle surface is

$$
D \mu / k T=1 /(6 \pi r)
$$

The radius, $r$, of the transporting species, based on the 
Table 1 Chloride ion diffusivities in the system 1-methyl-3-ethylımıdazolium chloride/aluminum chloride

\begin{tabular}{lcccc}
\hline Melt composition & $\begin{array}{c}\text { Diffusivity } \\
10^{7}\left(\mathrm{~cm}^{2} / \mathrm{s}\right)\end{array}$ & $\begin{array}{c}\text { Density } \\
\left(\mathrm{g} / \mathrm{cm}^{3}\right)\end{array}$ & $\begin{array}{c}\text { Viscosity } \\
(\mathrm{cP})\end{array}$ & $\begin{array}{c}D \mu / T \\
10^{10}\left(\mathrm{~g} \mathrm{~cm} / \mathrm{s}^{2} \mathrm{~K}\right)\end{array}$ \\
\hline Rotating cylinder electrodes & & & & \\
$0495(350 \mathrm{mV})$ & 58 & 1292 & 188 & 37 \\
$0495(700 \mathrm{mV})$ & 56 & 1292 & 188 & 36 \\
$0495+5 \mathrm{w} / \mathrm{o} \mathrm{CH}{ }_{3} \mathrm{CN}$ & 97 & 1252 & 90 & 30 \\
$0495+13 \mathrm{w} / \mathrm{CH}_{3} \mathrm{CN}$ & 23 & 1213 & 45 & 35 \\
$0490(350 \mathrm{mV})$ & 52 & 1290 & 199 & 35 \\
$0490(700 \mathrm{mV})$ & 50 & 1290 & 199 & 33 \\
$0490+5 \mathrm{w} / \mathrm{o} \mathrm{CH} \mathrm{CH}_{3} \mathrm{CN}$ & 98 & 1254 & 96 & 32 \\
$0490+13 \mathrm{w} / \mathrm{o} \mathrm{CH} \mathrm{CN}_{3} \mathrm{CN}$ & 23 & 1212 & 48 & 36 \\
$0485(350 \mathrm{mV})$ & 46 & 1288 & 212 & 32 \\
$0485+5 \mathrm{w} / \mathrm{o} \mathrm{CH} \mathrm{CH}_{3} \mathrm{CN}$ & 12 & 1255 & 103 & 41 \\
$0485+13 \mathrm{w} / \mathrm{O} \mathrm{CH}{ }_{3} \mathrm{CN}$ & 27 & 1206 & 47 & 42 \\
Average & & & & 35 \\
Rotating disk electrodes & & 1290 & 199 & 34 \\
$0490(350 \mathrm{mV})$ & 50 & 1290 & 199 & 37 \\
$0490(700 \mathrm{mV})$ & 55 & & & 35 \\
Average & & & & \\
\hline
\end{tabular}

average value of $D \mu / T$ of $35 \times 10^{-10} \mathrm{~g} \mathrm{~cm} / \mathrm{s}^{2} \mathrm{~K}$, was $21 \times 10^{-8} \mathrm{~cm}$, which is in close agreement with the reported value of chloride ion radius[15], 18 $\times 10^{-8} \mathrm{~cm} \mathrm{~A}$ previous study[16] of the chloride diffustvity in an $X=050$ melt found the $D \mu / T$ group to be $49 \times 10^{-10}$, which corresponds to a chloride ion radius about $30 \%$ smaller than that calculated here

Acknowledgements - The authors would like to express theır appreciation to John Ross who assisted in the measurement of the physical properties of the ternary electrolytes and wish to thank the Air Force Office of Scientific Research for financial support of this work under Grants Nos AFOSR85-0027 and AFOSR-88-0079

\section{REFERENCES}

1 L R Simonsen and F M Donahue, Proc 33rd Int Power Sources Symp, Electrochemical Society, Inc, Pennington (NJ), pp 346-350 (1988)

2 G F Reynolds and C J Dymek, J Power Sources 15, $109(1985)$

3 C J Dymek, G F Reynolds and J S Wilkes, $J$ electrochem Soc 134, 1658 (1987)

4 J Robinson and R A Osteryoung, $J$ electrochem Soc 127, $122(1980)$
5 A A Fannin, D A Florean, L A King, $J$ S Landers, B J Piersma, D J Stech, R L Vaughn, J S Wilkes and J L Williams Technical Report FJSRL-TR-82-0006, F J Seller Research Laboraroty, US Air Force Academy, CO (1982)

6 F M Donahue, Technical Memorandum FJSRL-TM84-0002, F J Seller Research Laboratoty, U S Air Force Academy, CO (1984)

7 M Eisenberg, C W Tobias and C R Wilke, $J$ electrochem Soc 101, 306 (1954)

8 D R Gabe and D J Robınson, Electrochim Acta 17, 1129 (1972)

9 N R K Vilambı and D -T Chın, $J$ electrochem Soc 134, 2501 (1987)

10 A J Arvia, J S W Carrozza and S C Marchiano, Electrochim Acta 9, 1483 (1964)

11 J S Wilkes, J A Levisky, R A Wilson and C L Hussey, Inorg Chem 21, 1263 (1982)

12 J S Wilkes, J A Levisky, J L Pflug, C L Hussey and T B Scheffler, Anal Chem 54, 2378 (1982)

$13 \mathrm{M}$ Eisenberg, C W Tobias and C R Wilke, Chem Engng Progr Symp Ser 51, 1 (1955)

14 V G Levich, Physicochemical Hydrodynamics, p 69 Prentice-Hall, New Jersey (1962)

15 F A Cotton and G W Wilkınson, Advanced Inorganıc Chemistry (4th edn), p 14 Wiley, New York (1980)

16 M Lipsztajn and R A Osteryoung, Inorg Chem 23, 1735 (1984) 